\title{
A rationalization of an African concept of life, death and the hereafter Offiong Offiong Asuquo
}

\author{
Dept. of Rel. Studies \& philosophy, University Of Calabar
}

\begin{abstract}
The Africans generally seem to have a common concept of life, death and the hereafter, which influences their lives and character greatly. An understanding of this African concept will enable the rest of the World (Non Africans), to improve relationship with Africans and vice versa. This is necessary because both camps have been involved in various forms of interactions, communications and commerce, and diplomatic contacts among others. This work attempts to construct, explain, critique and justify the African concept of life, death and the hereafter, in order to enhance this understanding, and consequently improve this relationship for the mutual benefits of both camps.
\end{abstract}

Keywords: African concept, life, death, hereafter

\section{INTRODUCTION}

Africans are generally and greatly influenced by their Traditional Religion. It has a pervasive role, and the whole of their life is wrapped up in religion. According to Opoku, Religion rounds up the totality of African Culture, a person does not need any special instruction in religion. He picks it up as he grows up and begins to participate in the communal rituals and ceremonies (11).

Due to this, the African concept of life, death and the hereafter is closely linked to and influenced by his traditional religion.

In order to properly rationalize the African concept of life, death and the hereafter, this paper attempts to construct, criticize and philosophise on such a concept.

The African Concept of Life: Francis Njoku summarizes the African concept of life into four points $(167-168)$ as follows:

Firstly, God is the originator of life, the creator of man, the universe and the sustainer of creation.

Secondly, the ancestors play an important role in the communal life. They are not cut off from the living, for they may still reveal themselves in dreams or appear to their living relatives to guide or correct them (Opoku 137).

Thirdly, life is a communal affair. It involves a relationship and communion between man, God, ancestors, divinities, other men and the land. This relationship must be based on certain rules and regulations for it to succeed (Njoku 169).

The above position is accepted by several scholars. Opoku agrees that God is the creator of the world and all that is in it. Next to God, are the ancestral spirits who play a very prominent role in African Traditional Religion (9).

Awolalu and Dopamu add to the first point by saying that in addition to creating men and the world, God also owns the world, man, and the society, and also sustains them (208).

Mbiti highlights another obvious aspect of life which is embedded in Njoku's first point, that is, the concept of human life in relation to time. This concept sees life as a rhythm or cycle which includes birth, puberty, initiation, marriage, procreation, old age, death, entry into the community of the departed and finally entry into the company of the spirits (24). This implies that God created man with the potentialities of passing through these stages of life. Every human being must go through them, although they vary according to cultures and time.

This work will attempt to rationalize the African concept of life in the next section.

A Rationalization of the African Concept of Life: A rationalization of the African concept of life will involve mainly a critique of the four points stated by Njoku above, among others. 
A look at the first assertion that God is the creator, source and sustainer of life, leads us to the field of philosophy of Religion where we may have to deploy one of the arguments often used to justify the existence and reality of God. The argument from Design, which states that the universe is a great machine made up of smaller machines. All these machines work in harmony with great accuracy. The argument adds that these machines resemble those designed by men although with a greater sophistication. Since the effects resemble each other, we are led to infer by the rules of analogy that the causes also resemble, thus the creator of nature is similar to the mind of man although he is far greater than man (Popkin \& Stroll 144), that creator must be God.

On the positive side, several scientific findings have strengthened this argument by revealing more amazing and carefully designed aspects of nature (Popkin \& Stroll 145).

On the negative side, this argument is greatly weakened by David Hume's attack on it, which states that the works of man and those of nature do not resemble each other sufficiently so that we can have any strong reason to suspect that they have similar causes. In other words, he is arguing that experience has taught us that human effects result from design, but we have no such experience with natural effects and how they happen to arise (Popkin \& Stroll 147). These two sides of the argument leave the ground even, but since the African has no other explanation for the source of life, he should be permitted to hold to his belief in God as the source.

A look at the second assertion about the important role of the ancestors in the communal life also raises questions about the authenticity of these roles. For instance, Opoku's comment that the ancestors are not cut off from the living, but may reveal themselves in dreams or appear to their living relatives to give instructions, warnings or information (137), raises an epistemological problem. This is due to the unreliability of sense data and knowledge.

Occasionally, it is discovered that what is believed to be true is proved dubious or false, and similarly, one may see something at a distance which turns out to be different when seen closely (Popkin \& Stroll, 169). Based on this, how can it be satisfactorily proved that those Africans who claim to have dreamt or interacted with any ancestor, were not suffering from this sense delusion? Furthermore, it should be noted that some dreams have turned out to be false and so an application of Descartes' view that if there is any reason for doubt, then the entire category ought to be treated as doubtful and unreliable (Popkin \& Stroll 169), will render dreams unreliable, as a basis of the African belief in the ancestors.

On the other hand, many Africans at different periods and places, have claimed to have had these experiences and dream of the ancestors to the extent that it will be unwise to entirely reject them as useless, furthermore, such claims and beliefs, have greatly influenced the African attitude to the ancestors.

The third assertion is that life is meaningless without land, which includes land and all other properties that make life worth living. This makes sense economically, because in order to survive, one needs food, clothing and shelter. In order to obtain these needs, one has to combine the three factors of production which include land, labour and capital. Thus, without the necessary equipment, tool or support, it is hard to achieve anything in life.

On the other hand, there are cases of the poor, orphans and destitute who virtually had nothing in life, but who still survive by providence. There are also cases of mystics, monks and recluses who deprive themselves of all earthly conveniences but still live meaningful lives. Therefore the third assertion that life is meaningless without land, should not be generalized.

Njoku's fourth assertion that life is a communal affair which involves a relationship and communion between man, God, ancestors, divinities, other men and the land, (169) is very obvious among many Africans. Mbiti supports this view by stating that to be human is to belong to the whole community, and to do so involves participating in the beliefs, ceremonies, rituals and festivals of that community (2).

This communal life starts from the family where the attachment and interaction among extended family members is strong, it extends to the village and clan level and the larger society. Such a relationship is mutually beneficial to the participants if they abide by certain rules, regulations and a commitment to its success (Francis Njoku, 170).

However, this does not occur always among Africans, many people often violate the laws and taboos of 
their communities. Many others do harmful things to their fellow men. Some are not interested in the welfare of their fellow men. There are many cases of family conflicts, intra and inter-tribal and communal wars among many African communities.

Furthermore, there are many Africans in the Diaspora who have been influenced by foreign cultures such that they are detached from such a communal life and live individualistic lives.

Similarly, the relationship between man on one hand, and God, the Ancestors and the Divinities on the other, is beneficial to man to the extent to which he can obey and please them. Those Africans who do not know or understand these divine beings and their laws and taboos very well will not be able to relate well with them. Thus, they will not enjoy a beneficial relationship with them.

Likewise the relationship between man and the land is important to the African. Land in this context, includes all natural resources which support life. The traditional African is attached to the land. History shows that in the past, the main occupations of most African communities included farming, hunting, fishing, and caring for livestock.

These occupations have continued till today, but with some improvements, expansions and modifications. The Africans exploit the land through these ways in order to support life. Due to this, they place great value on their land. Many of them are ready to fight to defend and prevent their land from being taken over by others. It is also a taboo to sell family land in some communities.

However, a closer look at the situation today shows that this traditional African attachment to land, is changing and diminishing. Due to urbanization and western education, many Africans have moved to urban areas and have acquired western education. These have detached them from their traditional occupations and the land. Furthermore many of them have secured white collar jobs which, further separate them from the land.

Nevertheless, despite the arguments against the four points highlighted by Francis Njoku as the basis of the African concept of life, it appears the generality of Africans, still hold on to them as the foci of their concept of life.
Physical life always ends at death, so the next section looks at the African concept of death.

The African Concept of Death: According to Idowu, the common Yoruba belief is that death is a creation of 'Olodumare' the creator, he was made for the purpose of recalling any person whose time on earth is fulfilled. Thus death is the inevitable lot of every person who comes into the world (187).

Mbiti sees death as a process, which removes a person gradually from the 'Sasa' period to the 'Zamani'. The Sasa period means the time of physical existence on earth and the period after death within which the departed is remembered by relatives and friends who knew him. When the last of these survivors die off, the departed now enters the 'Zamani' which is complete death (25).

An analysis of the above views shows that Mbiti agrees with Idowu over the inevitability of death, they also agree that death removes people from the world after a specific time, Idowu emphasizes the role of Olodumare as the originator of death, while Mbiti highlights death as an event that must occur as time moves on.

Opoku throws more light by stating that death is not the end of life, but a transition from this world to the land of the spirits. Death does not sever family connections, but the dead become ancestors (133).

Rosalind Hackett also confirms this view of death among the Efiks of Calabar (40).

From the foregoing, a picture of the African concept of death emerges as follows: Death is a creation of God, made for the purpose of removing people from the earth when their time is up (Idowu, 187). It happens gradually, starting from the time of one's departure from the earth physically, to the time when the last person who knew him physically, dies off (Mbiti 25). Death is a transition which involves transformation from the physical into the spiritual as the dead continue to live as ancestors (Opoku, 133).

A Rationalization of the African Concept of Death: This section mainly involves a critical consideration of the picture of the African concept of death which is painted above.

The statement that death is a creation of God made for the purpose of removing people from the world when their time is up seems like a follow up to 
Njoku's first point in the concept of life, that God is the source of life (167).

It follows logically that God who created life also takes it through death when the time is up.

The problem with this view is that it does not explain whether it is God who causes premature and undesirable deaths such as those caused by suicide, violence, accidents and drowning. Moreover, will God deliberately inflict such pains and sorrows that death often brings when He is seen as a loving father?

The second point which holds that death happens gradually between the time of one's physical departure from the earth and the time when the last person who knew him physically dies off (Mbiti 25), makes it to be a lengthy and cumbersome process. It is very hard to determine who is fully dead and who is still in the process of dying. It is also harder to find out the last person who knew a dead person and the time he also dies.

The third point that states that death is a transition which involves a transformation from the physical into the spiritual, as the dead continue to live as ancestors (Opoku, 133), is based on beliefs and subjective perceptions like dreams, visions and hallucinations which cannot be independently or scientifically verified.

Nevertheless, despite the arguments to the contrary, there appears to be no other plausible account for the origin of death apart from God. It is also not safe or wise to completely reject Mbiti's views of the gradual process of death, because one who still lives in the minds of people and affects and their lives, cannot be rightly said to be dead. Moreover the view that death is a transition and transformation from the physical into spiritual realm, even though it cannot be verified in anyway, yet neither can it be proved to be untrue. On the hand, many Africans have reasons to believe that their concept of death is true, and this affects and influences their lives positively.

The African Concept of the Hereafter: Many Africans believe that the dead go to the land of the spirits or ancestors which is underground. However some do not visualize any physical or geographical separation between the physical and spiritual world as they believe that the dead simply arrives there in his spirit form (Mbiti 160).
Opoku adds that in the afterlife, the dead are not cut off from the living, for they may reveal themselves in dreams or appear to their living relations to give instructions, warnings or information. They may summon living relatives to appear before them to explain their misconduct, and may punish them (137). However those who died bad deaths and those who lived bad lives cannot become ancestors, they are regarded as evil ghosts.

The dead are also believed to be able to return to the earth to be reborn into their families. This is shown by some of the names given to children. For instance 'Iyabo' in Yoruba means mother returns (Opoku, 138).

However, some Africans believe that the departed return to their creator, and the final destiny of man depends on how he lived on earth. God is believed to mete out judgment to men after death, and each has to give account of his earthly life (Opoku 139).

A Rationalization of the African Concept of the Hereafter: This will involve a critical look at the main points involved in the African concept of the Hereafter. Those points are summarized as follows: firstly the dead are believed to go to the land of the spirits or ancestors which is underground; secondly, they are not cut off from the living as they may reveal themselves in dreams or appear to the living. Thirdly they are believed to be able return to earth to be reborn into their families, and fourthly that the departed return to their creator to be judged by God according to how they lived on earth.

A look at the first point shows that this belief probably arose out of the general practice of burying the dead in the ground. However, it is hard to conceive of how this so called land of the dead will be able to contain all the spirits of the dead from time immemorial until the unforeseeable future. Their number keeps increasing daily and the earth is not expanding.

The second point which states that the dead still interact with the living through dreams or appearances, revisits the issue of the unreliability of sense perception. How reliable are such dreams and claims of appearances of ancestors? It is impossible to verify the truthfulness or falsity of these claims.

The third point which states that the dead are believed to be able to return to the earth to be reborn into their families is probably based on the possession of certain physical traits by some babies, 
similar to those possessed by their ancestors. However science has shown that such traits can be transferred down through genes and the blood.

The fourth point which states that the dead are believed to return to God to be judged according to how they lived on earth seems to contradict the first point which states that they return to the land of the spirits underground, and the third point which states that they are able to return to the earth to be reborn into their families. It is not possible for them to go to these places at once, and it is not clear whether they move from one to the other, and in which order and interval.

However this African concept of the afterlife is based on the beliefs of a variety of African communities, therefore there should be room for these variations and contradictions.

Summary and Conclusion: This work has attempted to rationalize an African concept of life, death and the hereafter, in the following way: Firstly it has constructed an African concept of life based in Francis Njoku's four point's basis of life as follows:

a. That God is the originator of life,

b. The ancestors are still involved in the communal lives of their people,

c. That life is meaningless without land

d. That life is a communal affair which involves relationships that are based on certain laws for mutual benefits and success.

Secondly, it has painted a picture of the African concept of death as follows: death is a creation of God, made for the purpose of removing people from the earth when their time is up. It happens gradually, starting from the time of one's departure from the earth physically to the time when the last person who knew him physically dies off. Death is a transition and transformation from the physical into the spiritual world.

Thirdly, it has also constructed an African concept of the hereafter as follows:
That the dead go to the land of the spirits which is underground. That they still interact with the living as ancestors. They are able to return to the earth to be reborn. That they do return to their creator to be rewarded or judged depending on how they lived.

A rationalization of all these points reveals that most arguments against them are not strong enough to debunk them as the basis of the African concept of life death and hereafter.

On the other hand, the Africans have strong reasons for holding to these beliefs. These beliefs are rooted in their traditional religion and culture which have existed and developed from time immemorial. The Africans are born into these beliefs and grow up with them.

However certain factors like western education, globalization, urbanization, foreign religions and modernization seem to be modifying and affecting the African concept of life, death and the hereafter.

It should also be noted that there are already some variations in this concept between one African community and the other.

Notwithstanding all these factors and arguments to the contrary, the picture of the African concept of life, death and the hereafter painted here could serve as a means of understandings the Africans more, and thus improve relations with them.

\section{REFERENCES}

Awolalu, J. O. and Dopamu, P. A. West African Traditional Religion. Ibadan, Onibonoje, 1979.

Hackett, R.I.J. Religion In Calabar. New York: Mouron De Gruyter, 1989.

Idowu, E. B. Olodumare God in Yoruba Belief. London: Longman Group, 1962.

Mbiti, J.S. African Religions And Philosophy. London: Heinemann, 1980.

Njoku, F.O.C. Essays In African Philosophy, Thought And Theology. Owerri: Clacom, 2002.

Opoku, K. A. West African Traditional Religion. Lagos: F. E. P., 1978

Popkin, R.H, and Stroll A. Philosophy Made Simple. London: Heinemann, 1981. 